\title{
Lenalidomide in heavily pretreated refractory diffuse large B-cell lymphoma: a case report
}

\author{
Katarzyna Krawczyk ${ }^{1}$, Wojciech Jurczak ${ }^{*}$, Krystyna Gałązka ${ }^{2}$, Andrzej Gruchała ${ }^{3}$ and Aleksander B Skotnicki ${ }^{1}$
}

\begin{abstract}
Introduction: In diffuse large B-cell lymphoma, first-line treatment with rituximab, cyclophosphamide, doxorubicin, vincristine and prednisone; salvage with cisplatin-based regimens for relapsing patients; and autologous stem cell therapy are standards of care. Treatment approaches are less clear for patients who are refractory or who are not candidates for autologous stem cell therapy. Options may include palliative regimens or clinical trial enrollment. One therapy under investigation in diffuse large B-cell lymphoma is lenalidomide, an immunomodulatory agent with antiangiogenic activity.

Case presentation: We present the case of a 55-year-old Caucasian male patient diagnosed with diffuse large B-cell lymphoma who had an early relapse after treatment with rituximab, cyclophosphamide, doxorubicin, vincristine, and prednisone. He then had a subsequent early relapse after cisplatin-based salvage consolidated with autologous stem cell therapy. The efficacy of gemcitabine-cisplatin-rituximab was limited to five months, followed by systemic and central nervous system progression. Fourth-line treatment with lenalidomide plus rituximab and involved-field radiotherapy followed by lenalidomide monotherapy greatly improved this patient's quality of life and performance status, allowing over two years of progression-free survival to date (excluding a brief relapse due to treatment interruption).
\end{abstract}

Conclusion: A lenalidomide-based regimen was highly effective in this patient with diffuse large B-cell lymphoma.

Keywords: Chemotherapy, Diffuse large B-cell lymphoma, Lenalidomide, Radioimmunotherapy, Rituximab

\section{Introduction}

Although diffuse large B-cell lymphoma (DLBCL) is an aggressive lymphoma, immunochemotherapy with rituximab, cyclophosphamide, doxorubicin, vincristine, and prednisone (R-CHOP) - widely regarded as the standard of care for first-line patients [1,2] - is effective in more than $50 \%$ of cases [3]. Treatment is not as defined for patients who are refractory or who relapse following standard first-line therapy. A number of agents are currently in development for treating relapsed or refractory DLBCL.

Lenalidomide (Revlimid', Celgene Corporation, Summit, New Jersey, USA) is an immunomodulatory agent that is approved for patients with previously treated multiple myeloma and for patients with myelodysplastic syndrome who have the $5 \mathrm{q}$ cytogenetic abnormality. Lenalidomide has both direct tumoricidal and immunomodulatory

\footnotetext{
* Correspondence: wojciech.jurczak@lymphoma.pl

'Department of Hematology, Jagiellonian University, Kopernika 17, Kraków 30-501, Poland

Full list of author information is available at the end of the article
}

effects. Direct effects include inhibition of vascular endothelial growth factor-mediated microvessel formation, indicating antiangiogenic and antimetastatic activities [4,5], as well as inhibition of nuclear factor kappa $\mathrm{B}$ to bring about cell cycle arrest and tumor cell death [6]. Immunomodulatory effects of lenalidomide include inhibition of pro-inflammatory cytokines such as tumor necrosis factor $\alpha$, increased anti-inflammatory cytokines such as interleukin-10, increased cytotoxicity of natural killer (NK) cells, and inhibition of regulatory $\mathrm{T}$ cells [7-11]. In addition, lenalidomide is a potent enhancer of NK cell-mediated and monocyte-mediated tumor cell antibody-dependent cellular cytotoxicity in nonHodgkin's lymphoma cells treated with the anti-CD20 monoclonal antibody rituximab [12].

Numerous studies of lenalidomide in DLBCL as monotherapy or in combination with other agents are ongoing in first-line patients and relapsed or refractory patients, as well as in the maintenance setting. In first-line patients with DLBCL, the combination of lenalidomide with rituximab 
plus CHOP (R2-CHOP) has yielded promising results in phase 1 and 2 studies [13-18]. In relapsed or refractory DLBCL, data from phase 2 studies of lenalidomide monotherapy and combination therapy with rituximab have been presented [19-24], and overall or objective response rates range from 28\% (DLBCL subset) [20] to $35 \%$ [21] in this setting. Based on presumptive cell of origin, there are two primary DLBCL subtypes with distinct pathophysiology: germinal center B-cell (GCB) and activated $\mathrm{B}$-cell (ABC)/non-GCB lymphoma. These are associated with different prognoses. The $\mathrm{ABC} /$ nonGCB subtype has a significantly poorer prognosis than the GCB subtype, and this correlation is independent of the International Prognostic Index (IPI) [25,26]. The benefit of lenalidomide may differ depending on the subtype of DLBCL [14,27]. In patients with relapsed or refractory DLBCL treated with salvage lenalidomide, a higher overall response rate (ORR) has been observed in patients with the non-GCB subtype compared with those with the GCB subtype (ORR $52.9 \%$ versus $8.7 \%$; $P=0.006)$ [27]. The benefit of lenalidomide has also been reported in newly diagnosed patients with nonGCB subtype DLBCL treated with R2-CHOP. In this setting, several small (<70 patients), phase 2 studies have demonstrated that the addition of lenalidomide improves progression-free survival and overcomes the negative prognostic impact of the non-GCB subtype on patient outcome $[14,18]$. An ongoing phase 2 randomized trial (NCT01856192) is comparing progression- free survival in patients with GCB and non-GCB DLBCL treated with first-line lenalidomide combined with R-CHOP versus R-CHOP alone [28]. In vitro studies indicate that the differential effects of lenalidomide on non-GCB DLBCL cells are dependent on the expression of interferon regulatory factor 4 and cereblon, an E3 ubiquitin ligase complex co-receptor protein [29].

Prognosis is poor for patients with multiply relapsed or refractory DLBCL, and current treatment guidelines suggest either autologous stem cell transplant (ASCT) or treatment within a clinical trial [1,2], underscoring the dearth of therapeutic options for this population. In this report, we present the case of a patient with DLBCL who received lenalidomide plus rituximab after multiple relapses on other treatments.

\section{Case presentation}

Our 55-year-old Caucasian male patient presented with a two-month history of gastrointestinal symptoms, including severe dyspepsia, vomiting, and 'black stool.' At that time, it was not clear whether our patient's weight loss $(14 \mathrm{~kg})$, high fever $\left(>38.5^{\circ} \mathrm{C}\right)$, and drenching night sweats were general symptoms or whether they were the result of an undiagnosed gastrointestinal tract disorder. The first histopathological confirmation of lymphoma came from a gastric biopsy sample (Figure 1) that confirmed CD20-positive DLBCL with a high proliferation fraction (expressed by Ki67 immunohistochemical stain, which was positive in $90 \%$ of the cells). Furthermore, the
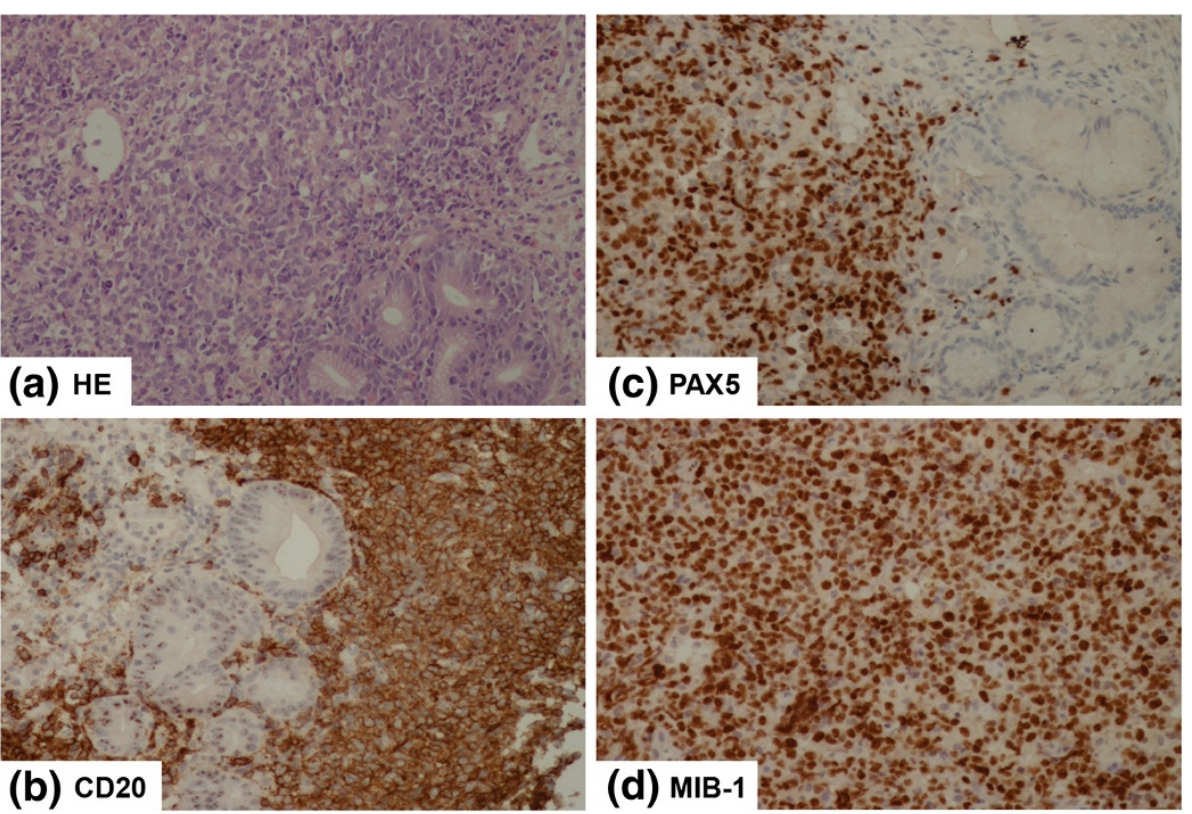

Figure 1 Initial histopathologic examination of the gastric biopsy specimen. (a) Gastric mucosa occupied (the left two-thirds of the image) by the diffuse infiltrate composed of large lymphoma cells. Hematoxylin and eosin (HE) stain, objective magnification 40x. (b) CD20 stain positivity in lymphoma cells, objective magnification 40x. (c) PAX5 stain positivity in lymphoma cells, objective magnification 40x. (d) High proliferative activity of diffuse large B-cell lymphoma cells on immunohistochemical staining for MIB-1 (Ki67), objective magnification 40X. 
cells were positive for MUM1 and negative for CD5 by immunohistochemistry. Our patient was referred from primary care to a hematologist following analysis of the gastric biopsy sample. By the time imaging studies were arranged (one week), generalized lymphadenopathy was evident, including a cervical lymph node that was nearly $8 \mathrm{~cm}$ in diameter. Positron emission and computed tomography (PET-CT) imaging demonstrated Ann Arbor stage IVB with enlarged submandibular, cervical, and mediastinal lymph nodes; lung and spleen nodules $(172 \mathrm{~mm})$; and gastric infiltration. At the beginning of therapy, our patient had a high IPI score of 4 .

In the first year of therapy (year 1), our patient was treated with standard R-CHOP chemotherapy (Table 1) from December of year 1 through May of year 2. A good clinical response was confirmed on $\mathrm{CT}$ imaging performed after cycles four and eight (treatment schema, Figure 2). Three months after completing first-line therapy, in August of year 2, a complete response (CR) status was further confirmed by a PET-CT scan that revealed cervical lymph nodes $(<20 \mathrm{~mm}$ in the long axis), with a standard uptake value (SUV) of 2.1, which was below mediastinal blood pool structure (MBPS) and liver maximum SUVs (SUVmax) and one $5 \mathrm{~mm}$ nodule in the fifth segment of his left lung.

Our patient's quality of life during first-line treatment was rather good; symptoms disappeared quickly. For the most part, he participated in normal daily activities. Treatment was conducted primarily in an outpatient setting.

In December of year 2, CT assessment suggested possible progression in cervical lymphadenopathy; early relapse was eventually confirmed by histopathology seven months after completion of the first-line therapy. As a second line of therapy, our patient received a regimen of rituximab, etoposide, methylprednisolone, cisplatin, and cytarabine (R-ESHAP) (Table 1) from March of year 3 to May of year 3.

A second CR was further consolidated by Z-BEAMconditioned (Y90-labeled ibritumomab tiuxetan (Zevalin ${ }^{\circ}$, Spectrum Pharmaceuticals, Henderson, Nevada, USA) combined with the carmustine, etoposide, cytarabine, and melphalan regimen (BEAM)) ASCT. An initial dose of rituximab in June of year 3 was followed a week later by a second rituximab dose plus Y90-labeled ibritumomab tiuxetan and BEAM-conditioned ASCT 11 days after initiating therapy. Our patient was released from the hospital in July of year 3, with good hematopoietic reconstitution and no complications.

At a three-month follow-up visit in October of year 3, our patient presented with no symptoms or abnormalities on physical examination. However, a small lesion was detected by PET-CT in his sternum $(12 \mathrm{~mm}$ in diameter, SUVmax 22.2, MBPS 3.2, liver SUVmax 3.8). A relapse of his DLBCL with high proliferation fraction was confirmed
Table 1 Treatment regimen for a heavily pretreated patient with diffuse large B-cell lymphoma

\begin{tabular}{ll}
\hline Rirst-line treatment & \\
\hline -CHOP $\times 8$ & Rituximab $375 \mathrm{mg} / \mathrm{m}^{2}$ (D1) \\
& Cyclophosphamide $750 \mathrm{mg} / \mathrm{m}^{2}$ (D1) \\
& Doxorubicin $50 \mathrm{mg} / \mathrm{m}^{2}$ (D1) \\
& Vincristine $1.4 \mathrm{mg} / \mathrm{m}^{2}$ (D1) \\
& Prednisone $40 \mathrm{mg} / \mathrm{m}^{2}$ (D1 to D5)
\end{tabular}

\section{Second-line treatment}

R-ESHAP $\times 3$

Rituximab $375 \mathrm{mg} / \mathrm{m}^{2}$ (D1)

Etoposide $40 \mathrm{mg} / \mathrm{m}^{2} /$ day (D1 to D4)

Methylprednisolone $500 \mathrm{mg} / \mathrm{m}^{2} /$ day (D1 to D4) ${ }^{\mathrm{b}}$

Cisplatin $25 \mathrm{mg} / \mathrm{m}^{2} /$ day (D1 to D4)

Cytarabine $2000 \mathrm{mg} / \mathrm{m}^{2}$ (D5)

Z-BEAM

Y90-labeled ibritumomab tiuxetan (ZEVALIN)

Carmustine

Etoposide

Cytarabine

Melphalan

Followed by rituximab $375 \mathrm{mg} / \mathrm{m}^{2}$, followed by Y 90 -labeled ibritumomab tiuxetan $32 \mathrm{mCiu} / \mathrm{kg}$ and BEAM (carmustine, etoposide, cytarabine, melphalan) -conditioned autologous stem cell transplant

Third-line treatment

$\begin{array}{ll} & \text { Gemcitabine } 1000 \mathrm{mg} / \mathrm{m}^{2} \text { (D1 to D5) } \\ & \text { Cisplatin } 80 \mathrm{mg} / \mathrm{m}^{2} \text { (D1 to D5) } \\ & \text { Rituximab } 375 \mathrm{mg} / \mathrm{m}^{2} \text { (D1 to D5) } \\ & \text { Prednisone } 60 \mathrm{mg} / \mathrm{m}^{2} \text { (D1 to D5) } \\ & \text { Followed by gemcitabine } 1,000 \mathrm{mg} / \mathrm{m}^{2} \\ & \text { (every two weeks) and rituximab } \\ & 375 \mathrm{mg} / \mathrm{m}^{2} \text { (every four weeks) } \\ \text { Intravenous steroids } & \text { Dexamethasone } 3 \times 8 \mathrm{mg} \\ & \text { Liposomal cytarabine } 50 \mathrm{mg} \text { (two doses) } \\ \text { Radiotherapy } & \text { Involved-field RT and prophylactic RT } \\ & \text { (26Gy per } 10 \text { fractions), then involved-field } \\ & \text { RT (8Gy per } 1 \text { fraction) }\end{array}$

Fourth-line treatment

Lenalidomide $25 \mathrm{mg}$

Rituximab $375 \mathrm{mg} / \mathrm{m}^{2}$ (every four weeks)

Palliative RT

Palliative RT

Lenalidomide $10 \mathrm{mg} /$ day for 21 days (every four weeks)

${ }^{\mathrm{a}}$ Maximum 2mg/dose; ${ }^{\mathrm{b}}$ maximum 1,000mg/dose; ${ }^{\mathrm{c}}$ continuous 24-hour infusion. D, day; Gy, gray; RT, radiotherapy.

in material from an urgent partial sternectomy (Figure 3). Despite this prompt procedure performed by thoracic surgeons, the disease progressed in the following months, as 


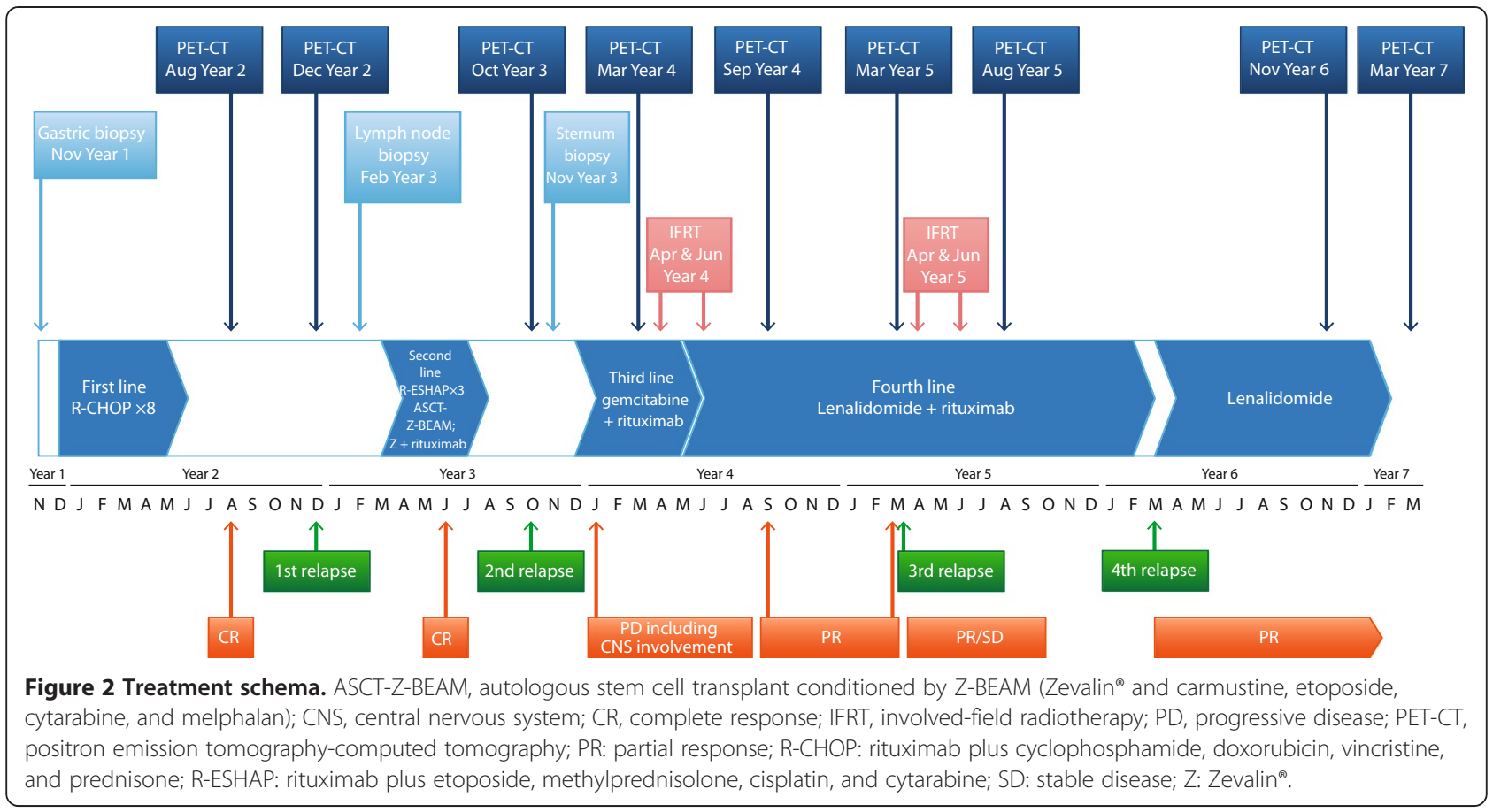

multiple bone lesions were found on subsequent PET imaging.

Our patient's quality of life during second-line treatment and ASCT was poor. There were extensive inpatient periods and side effects from the intensive chemotherapy.
Furthermore, his survival concerns caused great stress and discomfort.

In December of year 3, our patient started third-line, gemcitabine-based chemotherapy for debulking (Table 1). $\mathrm{He}$ received gemcitabine with cisplatin, rituximab, and
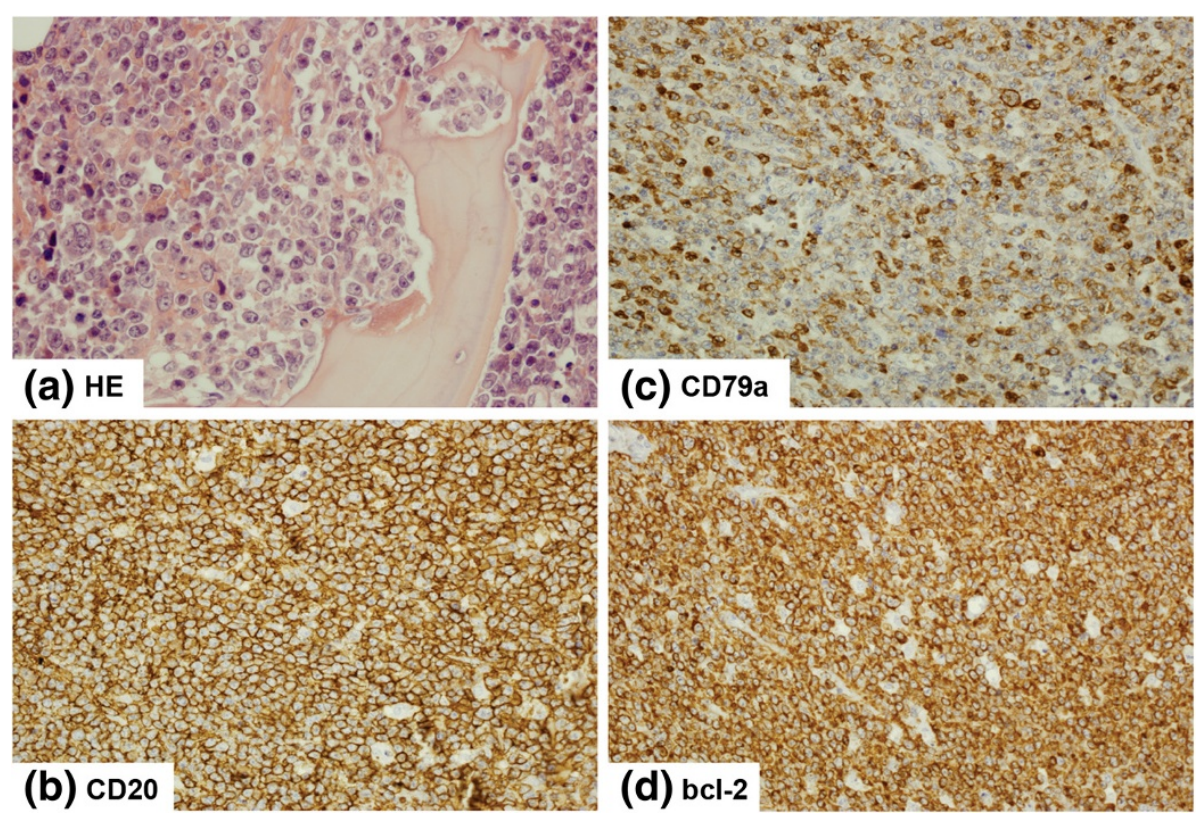

Figure 3 Relapse in the sternum. (a) A bone trabecula in the section of the sternal bone infiltrated and destroyed by diffuse large B-cell lymphoma (DLBCL) infiltrate. Hematoxylin and eosin (HE) stain, objective magnification 60x. (b) Strong expression of CD20 in the DLBCL cells, objective magnification 40x. (c) CD79a expression varying in intensity in some cells of the neoplastic infiltrate, objective magnification 40x. (d) Strong expression of the $\mathrm{BCl}-2$ protein in the $\mathrm{DLBCL}$ infiltrate, objective magnification 40x. 
prednisone. This was followed by gemcitabine every two weeks and rituximab every four weeks.

Beginning in January of year 4, our patient began to present unspecified, transient symptoms suggestive of central nervous system (CNS) involvement: headaches and signs of VII cranial nerve paralysis. Although this conclusion could not be definitively diagnosed by lumbar puncture with cerebrospinal fluid (CSF) cytology and repeated imaging studies (CT and magnetic resonance imaging), intrathecal liposomal cytarabine was given as CNS prophylaxis. In April of year 4, our patient presented with diplopia and right-side ptosis. CT scans demonstrated a left orbit tumor that infiltrated his frontal sinus. A neurological examination and CSF cytology were otherwise normal. Our patient received intravenous steroids and liposomal cytarabine, followed by involved-field radiotherapy (IFRT) of the orbit in April of year 4 and prophylactic radiotherapy of the CNS in May of year 4 (Table 1). The diplopia and ptosis resolved completely, but he developed bone pain in different locations. This was addressed by palliative IFRT in April of year 4.

During this period of treatment, our patient's quality of life remained poor. He was always either home-bound or hospitalized and was constantly undergoing medical procedures, including lumbar puncture. He experienced pain and the loss of some neurological function, and continued to be in great stress with survival fears.

Our patient remained on the rituximab therapy $\left(375 \mathrm{mg} / \mathrm{m}^{2}\right.$ every four weeks) initiated during third-line treatment. In May of year 4, he started fourth-line treatment with lenalidomide in addition to rituximab (Table 1). In June of year 4, he underwent a second round of palliative radiotherapy for bone lesions in locations corresponding with bone pain (Figure 4).
In September of year 4, PET-CT indicated a partial response; only two bone lesions were found (humeral end of his right clavicle: $17 \times 23 \mathrm{~mm}$, SUVmax 7.1 ; distal and proximal ends of his right tibia: SUV 4.9; MBPS 3.5, liver SUVmax 4.2). Our patient remained free of symptoms until March of year 5, when PET-CT (Figure 5) revealed lesions of increased SUV in his pelvis, bilateral femur and tibia, left ankle, and the humeral end of his right clavicle; SUVmax of these lesions was up to 4.5, MBPS 2.8. An osteolytic lesion in his T12 vertebra was also described. Palliative radiotherapy given in April and June of year 5 was again successful. His pain resolved, and in a PET-CT assessment in August of year 5, no new skeletal lesions were described. The existing lesions were not metabolically active (lesions in his right femur, SUV$\max$ 2.1; left femur, 1.8; bilateral tibias, 1.7 (MBPS 1.9, liver SUVmax 3.2)). The lenalidomide-plus-rituximab combination was continued until February of year 6, when treatment was halted for administrative reasons.

Six weeks after stopping lenalidomide-plus-rituximab therapy, our patient developed palpable lymphadenopathy of 5 to $10 \mathrm{~mm}$ on his neck, prompting initiation of lenalidomide monotherapy in March of year 6, which has continued to date. Due to grade 3 neutropenia as classified by the Common Terminology Criteria for Adverse Events (version 4.0) [30], the lenalidomide dose was reduced from 25 to $10 \mathrm{mg}$. Since the start of lenalidomide monotherapy, our patient has not experienced any progression, with a negative PET-CT in March of year 7, and has not experienced any bone pain or lesions.

Hematologic adverse events during lenalidomide-based treatment were manageable and comprised transient thrombocytopenia (platelets 39,000 to $80,000 / \mu \mathrm{L}$, no treatment required), and leuko- and neutropenia (white blood cells $<1000 / \mu \mathrm{L}$, polymorphonuclear cells $<500$;

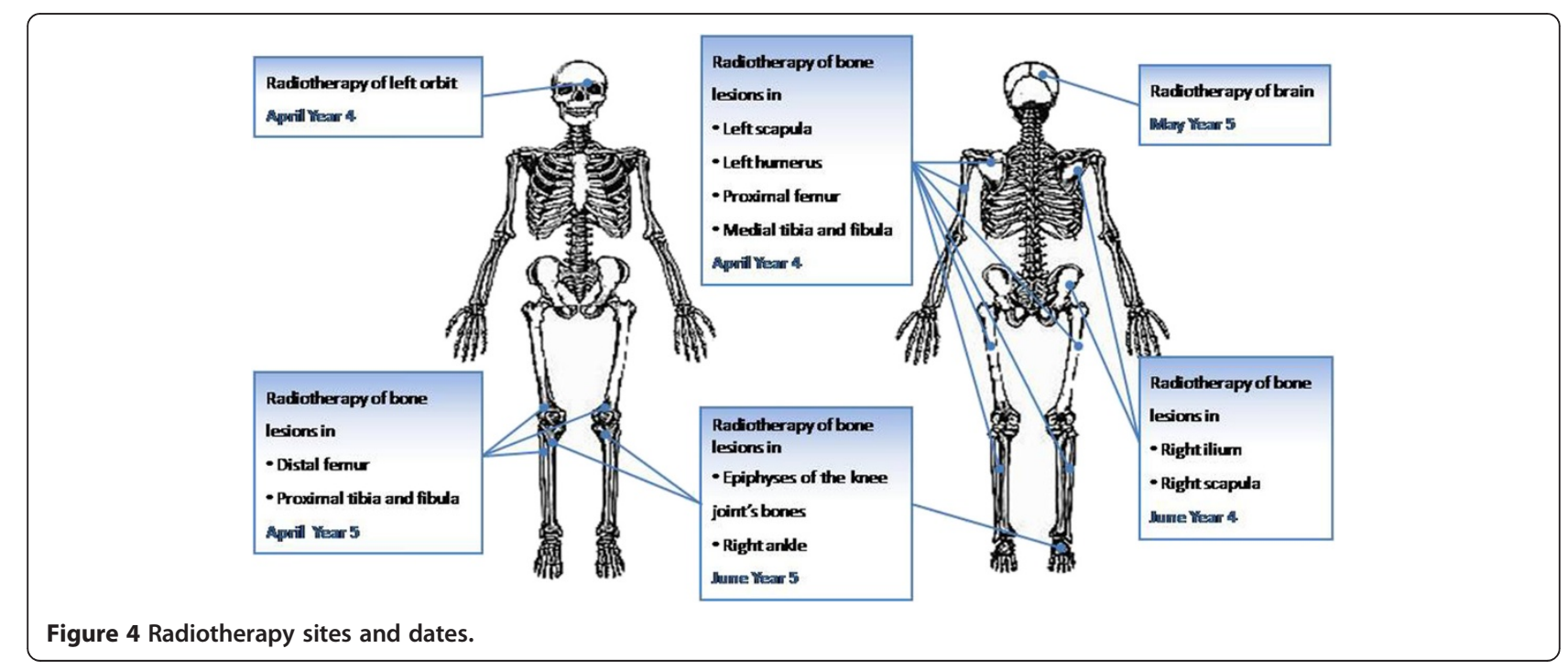



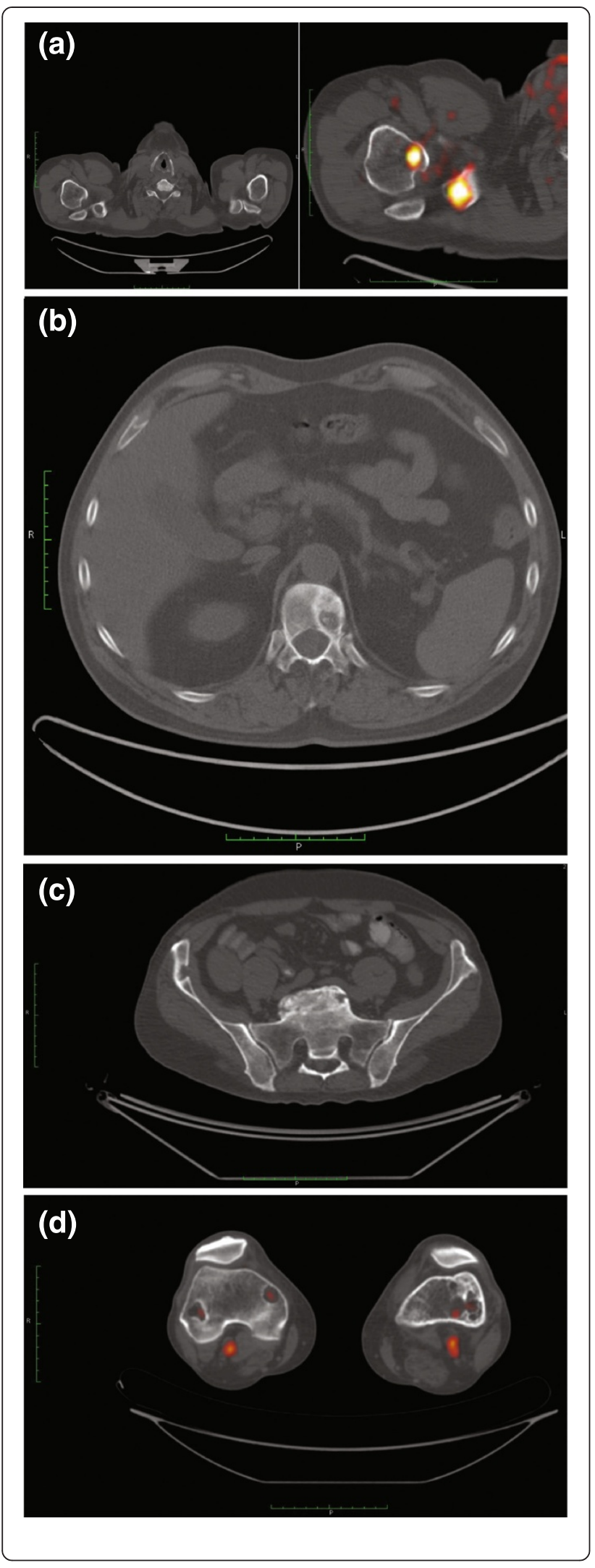

Figure 5 Positron emission tomography-computed tomography imaging of bone lesions. (a) Acromial extremity of the right clavicle, March of year 4. (b) Thoracic vertebra T12, March of year 4. (c) Right ilium, March of year 5. (d) Distal extremity of the femur bones, March of year 5 .

managed with granulocyte colony-stimulating factor support). The cytopenia was exacerbated during the concomitant palliative radiotherapy. Our patient developed two infections: sinusitis in March of year 5, which was treated with amoxicillin, and herpes (varicella zoster virus infection limited to the skin of his left cheek, with severe neuralgia) from July to October of year 5, which was treated with acyclovir and analgesics.

During treatment with lenalidomide plus rituximab and then later on lenalidomide monotherapy, our patient's quality of life and performance status remained surprisingly high (World Health Organization grade 0, Karnofsky score 100\%) and much improved compared with his quality of life and performance status during previous therapies. Inpatient hospitalization was not required, all procedures were performed in a day clinic, and he returned to full-time work and engaged in physical activities.

\section{Discussion}

DLBCL is the most common aggressive non-Hodgkin's lymphoma in adults and accounts for $25 \%$ to $35 \%$ of newly diagnosed cases [3,31]. Despite the significant advances with the addition of rituximab to $\mathrm{CHOP}$ chemotherapy [32,33], $30 \%$ to $40 \%$ of patients are refractory or relapse and eventually succumb. This is particularly frustrating in younger patients with a high proliferation fraction. Attempts to improve results in this subgroup have failed despite early intensification of first-line therapy or consolidation of the first CR with high-dose chemotherapy supported by ASCT [34]. Prognosis for patients with an early relapse after R-CHOP therapy in the first line is particularly poor [35,36], and much worse than previously reported by the PARMA trial [37].

Lenalidomide has an acceptable toxicity profile and is easily manageable and effective in heavily pretreated patients with high-grade lymphoma [38], based on results from four multicenter phase 2 trials by Wiernik et al. [19], Witzig et al. [20], Zinzani et al. [21], and Wang et al. [22]. The first two trials explored the efficacy of lenalidomide monotherapy in relapsing or refractory DLBCL. Lenalidomide ( $25 \mathrm{mg}$ for 21 or 28 days) resulted in ORR up to $37 \%$ [22] and median progression-free survival up to four months $[19,22]$, with median duration of response from 4.6 to 16 months $[20,21]$. In the third trial, four cycles of lenalidomide, rituximab, and dexamethasone induction were followed by lenalidomide maintenance [21]. Although the ORR was similar (35\%), it was long-lasting in 
patients receiving lenalidomide maintenance. Toxicity was manageable and well-tolerated, despite the heavily pretreated population. The most frequent grade 3 or 4 adverse events were hematologic (neutropenia 30\%, thrombocytopenia $14 \%$, asthenia $5 \%$, and anemia 5\%) [21]. These results are confirmed by case reports from everyday practice. For example, Rubenstein et al. reported remarkable regression of refractory intraocular DLBCL during monotherapy with lenalidomide [39]. Lenalidomide is not standard treatment for DLBCL at our institution, although we had previously observed positive results among our patients participating in clinical trials of lenalidomide for refractory non-Hodgkin's lymphoma.

In our patient, we observed an early relapse after firstline $\mathrm{R}-\mathrm{CHOP}$ chemotherapy, indicating a dynamic and aggressive lymphoma with poor prognosis. Although radioimmunotherapy (ibritumomab tiuxetan) was added to a BEAM conditioning regimen supported by ASCT, it did not overcome disease resistance. Considering the rapid progression of lymphoma at each relapse, it is very unlikely that local, palliative radiotherapy would have effectively cured the disease and prevented distant relapses. Treatment with lenalidomide was considered under compassionate use after failure of all other treatments available at our institution. The lenalidomiderituximab regimen was based on Wiernik and Witzig protocols [19,20]; however, dexamethasone was omitted to minimize the risk of osteoporosis and compression fractures in a patient with lymphoma-infiltrated vertebrae. This regimen changed the lymphoma dynamics, allowing more effective radiotherapy and possibly preventing its spread to distant sites, and provided the longest progression-free survival (eight months after the R-CHOP chemotherapy and three months after Z-BEAM ASCT versus 12 months on lenalidomide-rituximab until treatment break followed by $>12$ months during lenalidomide monotherapy). Our patient's quality of life was excellent and greatly improved compared with previous therapies, treatment was outpatient-based, and he returned to work. Furthermore, this positive clinical response and improved quality of life were maintained despite treatment interruption and continuation as lenalidomide monotherapy for over 10 months.

\section{Conclusions}

We demonstrate that lenalidomide can be efficacious in DLBCL, and we believe that it should be considered in relapsed or refractory DLBCL, particularly for heavily pretreated patients.

\section{Consent}

Written informed consent was obtained from the patient for publication of this case report and accompanying images. A copy of the written consent is available for review by the Editor-in-Chief of this journal.

\section{Abbreviations}

ABC: Activated B-cell; ASCT: Autologous stem cell transplant; BEAM: Carmustine etoposide, cytarabine, and melphalan; CHOP: Cyclophosphamide doxorubicin, vincristine, and prednisone; CNS: Central nervous system; CR: Complete response; CSF: Cerebrospinal fluid; $C$ : Computed tomography; DLBCL: Diffuse large B-cell lymphoma; GCB: Germinal center B-cell; HE: Hematoxylin and eosin; IFRT: Involved-field radiotherapy; IPI: International Prognostic Index; MBPS: Mediastinal blood pool structures; NK: Natural killer; ORR: Overall response rate; PD: Progressive disease; PET-CT: Positron emission and computed tomography; PR: Partial response; R-CHOP: Rituximab plus cyclophosphamide doxorubicin, vincristine, and prednisone; R-ESHAP: Rituximab plus etoposide methylprednisolone, cisplatin, and cytarabine; SD: Stable disease; SUV: Standard uptake value; SUVmax: Maximum standard uptake value; Z: Zevalin.

\section{Competing interests}

The authors declare that they have no competing interests.

\section{Authors' contributions}

$\mathrm{KK}, \mathrm{WJ}, \mathrm{KG}, \mathrm{AG}$, and $\mathrm{ABS}$ wrote the paper. All authors read and approved the final manuscript.

\section{Acknowledgments}

We thank Tamara Fink, PhD, of ProEd Communications, Beachwood, Ohio, USA, for medical editorial assistance with this case report. Support for medical editorial assistance was provided by Celgene Corporation, Summit, New Jersey, USA.

\section{Author details}

'Department of Hematology, Jagiellonian University, Kopernika 17, Kraków 30-501, Poland. ²Department of Pathology, Jagiellonian University, Kraków, Poland. ${ }^{3}$ Department of Tumor Pathology, Center of Oncology, M. Sklodowska-Curie Memorial Institute, Cracow Branch, Kraków, Poland.

Received: 15 May 2014 Accepted: 21 July 2014

Published: 2 October 2014

\section{References}

1. NCCN Clinical Practice Guidelines in Oncology: Non-Hodgkin's Lymphoma. Version 1. 2014, 12/20/13. 2014, [http://www.nccn.org/professionals/ physician gls/pdf/nhl.pdf]

2. Tilly $\mathrm{H}$, Vitolo U, Walewski J, da Silva MG, Shpilberg O, Andre M, Pfreundschuh M, Dreyling M: Diffuse large B-cell lymphoma (DLBCL): ESMO Clinical Practice Guidelines for diagnosis, treatment and follow-up. Ann Oncol 2012, 23(Suppl 7):viiiz-vii82.

3. Gisselbrecht C, Mounier N: Novel agents for diffuse large B-cell lymphoma. In 2011 Educational Book. Alexandria, VA: American Society of Clinical Oncology; 2011:321-325.

4. Lu L, Payvandi F, Wu L, Zhang LH, Hariri RJ, Man HW, Chen RS, Muller GW, Hughes CC, Stirling DI, Schafer PH, Bartlett JB: The anti-cancer drug lenalidomide inhibits angiogenesis and metastasis via multiple inhibitory effects on endothelial cell function in normoxic and hypoxic conditions. Microvasc Res 2009, 77:78-86.

5. Reddy N, Hernandez-llizaliturri FJ, Deeb G, Roth M, Vaughn M, Knight J, Wallace P, Czuczman MS: Immunomodulatory drugs stimulate natural killer-cell function, alter cytokine production by dendritic cells, and inhibit angiogenesis enhancing the anti-tumour activity of rituximab in vivo. Br J Haematol 2008, 140:36-45.

6. Davis RE, Brown KD, Siebenlist U, Staudt LM: Constitutive nuclear factor kappaB activity is required for survival of activated $B$ cell-like diffuse large B cell lymphoma cells. J Exp Med 2001, 194:1861-1874.

7. Corral LG, Haslett PA, Muller GW, Chen R, Wong LM, Ocampo CJ, Patterson RT, Stirling DI, Kaplan G: Differential cytokine modulation and T cell activation by two distinct classes of thalidomide analogues that are potent inhibitors of TNF-alpha. J Immunol 1999, 163:380-386.

8. Galustian C, Meyer B, Labarthe MC, Dredge K, Klaschka D, Henry J, Todryk S, Chen R, Muller G, Stirling D, Schafer P, Bartlett JB, Dalgleish AG: The anticancer agents lenalidomide and pomalidomide inhibit the proliferation 
and function of T regulatory cells. Cancer Immunol Immunother 2009, 58:1033-1045.

9. Hayashi T, Hideshima T, Akiyama M, Podar K, Yasui H, Raje N, Kumar S, Chauhan D, Treon SP, Richardson P, Anderson KC: Molecular mechanisms whereby immunomodulatory drugs activate natural killer cells: clinical application. Br J Haematol 2005, 128:192-203.

10. Hsu AK, Quach H, Tai T, Prince HM, Harrison SJ, Trapani JA, Smyth MJ, Neeson P, Ritchie DS: The immunostimulatory effect of lenalidomide on NK-cell function is profoundly inhibited by concurrent dexamethasone therapy. Blood 2011, 117:1605-1613.

11. Schafer PH, Gandhi AK, Loveland MA, Chen RS, Man HW, Schnetkamp PP, Wolbring G, Govinda S, Corral LG, Payvandi F, Muller GW, Stirling DI: Enhancement of cytokine production and AP-1 transcriptional activity in T cells by thalidomide-related immunomodulatory drugs. J Pharmacol Exp Ther 2003, 305:1222-1232.

12. Wu L, Adams M, Carter T, Chen R, Muller G, Stirling D, Schafer P, Bartlett JB: Lenalidomide enhances natural killer cell and monocyte-mediated antibody-dependent cellular cytotoxicity of rituximab-treated CD20+ tumor cells. Clin Cancer Res 2008, 14:4650-4657.

13. Chiappella A, Tucci A, Castellino A, Pavone V, Baldi I, Carella AM, Orsucci L, Zanni M, Salvi F, Liberati AM, Gaidano G, Bottelli C, Rossini B, Perticone S, De Masi P, Ladetto M, Ciccone G, Palumbo A, Rossi G, Vitolo U, Fondazione Italiana Linfomi: Lenalidomide plus cyclophosphamide, doxorubicin, vincristine, prednisone and rituximab is safe and effective in untreated, elderly patients with diffuse large B-cell lymphoma: a phase I study by the Fondazione Italiana Linfomi. Haematologica 2013, 98:1732-1738.

14. Nowakowski G, Reeder CB, Foran JM, Porrata LF, Macon WR, Johnston PB, Rivera CE, Habermann TM, Inwards DJ, Micallef IN, Johnston PB, Porrata LF, Ansell SM, Klebig RR, Reeder CB, Witzig TE: Combination of lenalidomide with RCHOP (R2CHOP) overcomes negative prognostic impact of nonGCB phenotype in DLBCL-a phase 2 study. Hematol Oncol 2013, 31(Suppl 1):168. abstract 213

15. Nowakowski GS, LaPlant B, Habermann TM, Rivera CE, Macon WR, Inwards DJ, Micallef IN, Johnston PB, Porrata LF, Ansell SM, Klebig RR, Reeder CB, Witzig TE: Lenalidomide can be safely combined with R-CHOP (R2CHOP) in the initial chemotherapy for aggressive B-cell lymphomas: phase I study. Leukemia 2011, 25:1877-1881.

16. Nowakowski GS, LaPlant BR, Reeder C, Foran JM, Porrata LF, Macon WR, Johnston PB, Rivera CE, Habermann TM, Inwards DJ, Micallef IN, Johnston PB, Porrata LF, Ansell SM, Klebig RR, Reeder CB, Witzig TE: Combination of lenalidomide with $\mathrm{R}-\mathrm{CHOP}(\mathrm{R} 2 \mathrm{CHOP})$ is well-tolerated and effective as initial therapy for aggressive B-cell lymphomas - a phase II study. Blood

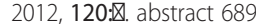

17. Tilly H, Morschhauser F, Salles G, Casasnovas RO, Feugier P, Molina TJ, Jardin F, Terriou L, Haioun C, Coiffier B: Phase 1b study of lenalidomide in combination with rituximab-CHOP (R2-CHOP) in patients with B-cell lymphoma. Leukemia 2013, 27:252-255.

18. Vitolo U, Chiappella A, Franceschetti S, Carella AM, Baldi I, Inghirami G, Spina M, Pavone V, Ladetto M, Liberati AM, Molinari AL, Zinzani P, Salvi F, Fattori PP, Zaccaria A, Dreyling M, Botto B, Castellino A, Congiu A, Gaudiano M, Zanni M, Ciccone G, Gaidano G, Rossi G, Fondazione Italiana Linfomi: Lenalidomide plus R-CHOP21 in elderly patients with untreated diffuse large B-cell lymphoma: results of the REAL07 open-label, multicentre, phase 2 trial. Lancet Oncol 2014, 15:730-737.

19. Wiernik PH, Lossos IS, Tuscano JM, Justice G, Vose JM, Cole CE, Lam W, McBride K, Wride K, Pietronigro D, Takeshita K, Ervin-Haynes A, Zeldis JB, Habermann TM: Lenalidomide monotherapy in relapsed or refractory aggressive non-Hodgkin's lymphoma. J Clin Oncol 2008, 26:4952-4957.

20. Witzig TE, Vose JM, Zinzani PL, Reeder CB, Buckstein R, Polikoff JA, Bouabdallah R, Haioun C, Tilly H, Guo P, Pietronigro D, Ervin-Haynes AL, Czuczman MS: An international phase II trial of single-agent lenalidomide for relapsed or refractory aggressive B-cell non-Hodgkin's lymphoma. Ann Oncol 2011, 22:1622-1627.

21. Zinzani PL, Pellegrini C, Gandolfi L, Stefoni V, Quirini F, Derenzini E, Broccol A, Argnani L, Pileri S, Baccarani M: Combination of lenalidomide and rituximab in elderly patients with relapsed or refractory diffuse large B-cell lymphoma: a phase 2 trial. Clin Lymphoma Myeloma Leuk 2011, 11:462-466

22. Wang M, Fowler N, Wagner-Bartak N, Hagemeister F, Neelapu S, Fanale M, Younes A, Zhang L, Sun L, Badillo M, Bejarano M, Champlin R, Kwak L, Feng L, Byrne C, Bell N, Zeldis J, Romaguera J, Fayad L: Oral lenalidomide plus 4 doses of rituximab induced prolonged remissions in a cohort of patients with DLBCL and grade 3 follicular lymphoma: a completed phase II clinical trial. Haematologica 2012, 97(Suppl 1):95. abstract 0237.

23. Wang M, Fowler N, Wagner-Bartak N, Feng L, Romaguera J, Neelapu SS, Hagemeister F, Fanale M, Oki Y, Pro B, Shah J, Thomas S, Younes A, Hosing C, Zhang L, Newberry K, Desai M, Cheng N, Badillo M, Bejarano M, Chen Y, Young $\mathrm{KH}$, Champlin R, Kwak L, Fayad L: Oral lenalidomide with rituximab in relapsed or refractory diffuse large cell, follicular and transformed lymphoma: a phase II clinical trial. Leukemia 2013, 27:1902-1909.

24. Zinzani PL, Pellegrini C, Derenzini E, Argnani L, Pileri S: Long-term efficacy of the combination of lenalidomide and rituximab in elderly relapsed/ refractory diffuse large B-cell lymphoma patients. Hematol Oncol 2013, 31:223-224.

25. Alizadeh AA, Eisen MB, Davis RE, Ma C, Lossos IS, Rosenwald A, Boldrick JC, Sabet H, Tran T, Yu X, Powell JI, Yang L, Marti GE, Moore T, Hudson J Jr, Lu L, Lewis DB, Tibshirani R, Sherlock G, Chan WC, Greiner TC, Weisenberger DD, Armitage JO, Warnke R, Levy R, Wilson W, Grever MR, Byrd JC, Botstein D, Brown PO, Staudt LM: Distinct types of diffuse large B-cell lymphoma identified by gene expression profiling. Nature 2000, 403:503-511.

26. Rosenwald A, Wright G, Chan WC, Connors JM, Campo E, Fisher RI, Gascoyne RD, Muller-Hermelink HK, Smeland EB, Giltnane JM, Hurt EM, Zhao H, Averett L, Yang L, Wilson WH, Jaffe ES, Simon R, Klausner RD, Powell J, Duffey PL, Longo DL, Greiner TC, Weisenberger DD, Sanger WG, Dave BJ, Lynch JC, Vose J, Armitage JO, Montserrat E, López-Guillermo A: The use of molecular profiling to predict survival after chemotherapy for diffuse large-B-cell lymphoma. N Engl J Med 2002, 346:1937-1947.

27. Hernandez-llizaliturri FJ, Deeb G, Zinzani PL, Pileri SA, Malik F, Macon WR, Goy A, Witzig TE, Czuczman MS: Higher response to lenalidomide in relapsed/refractory diffuse large B-cell lymphoma in nongerminal center B-cell-like than in germinal center B-cell-like phenotype. Cancer 2011, 117:5058-5066.

28. NCT01856192: Rituximab and Combination Chemotherapy With or Without Lenalidomide in Treating Patients With Newly Diagnosed Stage II-IV Diffuse Large B Cell Lymphoma. [http://clinicaltrials.gov/ct2/show/ NCT01856192]

29. Zhang LH, Kosek J, Wang M, Heise C, Schafer PH, Chopra R: Lenalidomide efficacy in activated B-cell-like subtype diffuse large B-cell lymphoma is dependent upon IRF4 and cereblon expression. Br J Haematol 2013, 160:487-502.

30. US Department of Health and Human Services, National Institutes of Health, National Cancer Institute. Common Terminology Criteria for Adverse Events, version 4.0. 2009, [http://evs.nci.nih.gov/ftp1/CTCAE/About.html]

31. Cultrera JL, Dalia SM: Diffuse large B-cell lymphoma: current strategies and future directions. Cancer Control 2012, 19:204-213.

32. Coiffier B, Lepage E, Briere J, Herbrecht R, Tilly H, Bouabdallah R, Morel P, Van Den Neste E, Salles G, Gaulard P, Reyes F, Lederlin P, Gisselbrecht C: CHOP chemotherapy plus rituximab compared with $\mathrm{CHOP}$ alone in elderly patients with diffuse large-B-cell lymphoma. N Engl J Med 2002, 346:235-242.

33. Feugier $P$, Van Hoof $A$, Sebban $C$, Solal-Celigny $P$, Bouabdallah $R$, Ferme $C$, Christian B, Lepage E, Tilly H, Morschhauser F, Gaulard P, Salles G, Bosly A, Gisselbrecht C, Reyes F, Coiffier B: Long-term results of the R-CHOP study in the treatment of elderly patients with diffuse large B-cell lymphoma: a study by the Groupe d'Etude des Lymphomes de l'Adulte. J Clin Oncol 2005, 23:4117-4126.

34. Schmitz N, Nickelsen M, Ziepert M, Haenel M, Borchmann P, Schmidt C, Viardot A, Bentz M, Peter N, Ehninger G, Doelken G, Ruebe C, Truemper L, Rosenwald A, Pfreundschuh M, Loeffler M, Glass B, German High-Grade Lymphoma Study Group (DSHNHL): Conventional chemotherapy (CHOEP-14) with rituximab or high-dose chemotherapy (MegaCHOEP) with rituximab for young, high-risk patients with aggressive B-cell lymphoma: an open-label, randomised, phase 3 trial (DSHNHL 2002-1). Lancet Oncol 2012, 13:1250-1259.

35. Gisselbrecht C: Is there any role for transplantation in the rituximab era for diffuse large B-cell lymphoma? Hematology Am Soc Hematol Educ Program 2012, 2012:410-416.

36. Gisselbrecht C, Glass B, Mounier N, Singh Gill D, Linch DC, Trneny M, Bosly A, Ketterer N, Shpilberg O, Hagberg H, Ma D, Brière J, Moskowitz CH, Schmitz N: Salvage regimens with autologous transplantation for relapsed large B-cell lymphoma in the rituximab era. J Clin Oncol 2010, 28:4184-4190.

37. Guglielmi C, Gomez F, Philip T, Hagenbeek A, Martelli M, Sebban C, Milpied N, Bron D, Cahn JY, Somers R, Sonneveld P, Gisselbrecht C, Van Der Lelie H, 
Chauvin F: Time to relapse has prognostic value in patients with aggressive lymphoma enrolled onto the Parma trial. J Clin Oncol 1998, 16:3264-3269.

38. Chiappella A, Vitolo U: Lenalidomide in diffuse large B-cell lymphomas. Adv Hematol 2012, 2012:498342.

39. Rubenstein JL, Treseler PA, Stewart PJ: Regression of refractory intraocular large B-cell lymphoma with lenalidomide monotherapy. J Clin Oncol 2011, 29:e595-e597.

doi:10.1186/1752-1947-8-325

Cite this article as: Krawczyk et al.: Lenalidomide in heavily pretreated

refractory diffuse large B-cell lymphoma: a case report. Journal of Medical Case Reports 2014 8:325.

\section{Submit your next manuscript to BioMed Central and take full advantage of:}

- Convenient online submission

- Thorough peer review

- No space constraints or color figure charges

- Immediate publication on acceptance

- Inclusion in PubMed, CAS, Scopus and Google Scholar

- Research which is freely available for redistribution 